\title{
METAPHORISATION OF WOMEN IN YORUBA PROVERBS: A FEMINIST CRITICAL ANALYSIS
}

\author{
Adetutu Aragbuwai, \\ Samuel A. Omotunde \\ Department of English \& Literary Studies, \\ Ekiti State University, \\ Ado-Ekiti, Nigeria
}

\begin{abstract}
:
Studies on conceptual metaphors in gender-based proverbial discourses have gained much scholarly attention in linguistic studies. In spite of this, conceptual metaphorisations in gendered Yoruba proverbs still remain under-researched. This study seeks to fill the gap by exploring conceptual metaphorisations in gender-based Yoruba proverbs using linguistic frameworks. The data comprise 100 Yoruba proverbs on women. The Conceptual Metaphor Theory and Feminist Critical Discourse Analysis guide the analysis. The data analysis reveals that, four (4) conceptual metaphors structure women in the select proverbs: Women Are Weaklings; Women Are Evil; Women Are Whores; and, Women Are Procreants. The first three conceptual metaphors generically give women a "downward orientation". The fourth assumedly underlines an "upward orientation", which implicitly entails a down orientation. The downward image schema of these four metaphors indicates that, among the Yoruba, women are profiled negatively. This profiling reveals that the Yoruba's ideological gender structure advances a hierarchical order in which women are subordinated to men.
\end{abstract}

Keywords: gender, conceptual, metaphors, criticism, hegemony

\section{Introduction}

Proverbs are richly flavored, pithy and fixed oral expressions that epitomise the essence of most African cultures; hence, they are conceptual literary expressions metaphorically, poetically and aesthetically used to mirror the cultural worldviews, social and moral values, ethos and experiences of Africans from generation to generation (Finnegan, 2012; Doyle, 2007; Mieder, 2004; Hussein, 2005). They "fulfill the human need to summarise experiences and observations into nuggets of wisdom that provide ready-made comments on personal relationships and social affairs" (Mieder, 2004, p. 1). Although proverbs are universal, Africans use them more to "accomplish acts that ordinary words cannot realise" (Fakoya 2007, p. 2). A proverbial expression in the African culture is, therefore, a literary expression embellished to "give depth and elegance through its

' Correspondence: email aragbuwa.adetutu@eksu.edu.ng, adebayo.omotunde@eksu.edu.ng 
allusive, figurative, and poetic mode..." (Finnegan, 2012, p. 403). And every African culture has its collection of proverbs, oral and/or written, that embodies the philosophical constructs of the populace as regards social, political, religious and interactive situations.

In the Yoruba culture, for instance, any utterance bereft of proverbs will be considered devoid of freshness, clarity and efficacy. Yoruba owe (Yoruba proverbs) are regarded as verbal embellishments commonly deployed in both formal and informal contexts among the Yoruba people that occupy largely the southwestern geo-political zone of Nigeria (Owomoyela, 2005; Asiyanbola, 2009). To the Yoruba therefore, proverbs are the salt of speech; their terse but forceful semantic and rhetorical import makes them an integral aspect of the Yoruba linguistic signs. This is demonstrated in the proverb: "owe lẹsin oro, bí oro-o bá sọù, owe la fi ńwá a (the proverb is the horse of speech, when speech is lost, the proverb is the means we use to hunt for it)" (Owomoyela, 2005, p. 12). Every Yoruba native is expected to be well versed in the application and comprehension of Yoruba proverbs in dialogues (Daramola, 2007). Yoruba proverbs could be delineated on the basis of honesty/truth, wisdom, good name, morality, religion, deity, aesthetics, rituals, music, sacrifices, occupation, diligence, perseverance, traditional education, justice, afterlife, courage/cowardice, conflict and resolution, power and leadership, and most importantly, gender (Salami 2004; Asiyanbola, 2007; Owomoyela, 2005; Daramola, 2004, 2013; Saleh, 2014; Sibanda, 2015).

Gender issues are highly prominent in Yoruba proverbs, with many literally spotlighting men's and women' normative behavioral traits, positions and responsibilities as well as their expected rights and rewards in the society. This has consequently led to the preponderance of academic discourse on gender representation in Yoruba proverbs, specifically women's representation, the lead concern in this treatise. Scholars such as Oha (1998), Owomoyela (2005), Daramola (2007), Asiyanbola (2009) and Balogun (2010) have explored positive and negative representations of women in Yoruba proverbs. Thus, Yoruba proverbs embody pejorative and complimentary statements about women, although the former is said to outweigh the latter (Balogun, 2010; Anthonia, 2019), a situation presumed to have reinforced and sustained gendered culture in the Yoruba society (Hussein, 2004, 2005; Mwihia, 2005). The present study, therefore, seeks to expand the literature on women's representation in Yoruba proverbs by applying linguistic and feminist frameworks to explore metaphorisations in the representation of women in gender-based Yoruba proverbs.

Every language is structured metaphorically; in a similar vein, proverbial discourses too are metaphorically structured (Lakoff \& Johnson, 1980a, p. 455). Mieder (1993), Finnegan (2012) and Saleh (2014) opine that, proverbs are commonly constructed in a metaphorical form. Cognitively, metaphors enable mankind to "understand one conceptual domain in terms of another conceptual domain" (Kövecses, 2010, p. 4). In recent times in linguistic enquiries, studies on conceptual metaphor in gender-based proverbial discourses have gained much scholarly attention, with scholars exploring the interplay of metaphoric concepts and genderisation in Persian proverbs (Estaji \& Nakhavali, 2011), Bukusu and Gusii proverbs (Barasa \& Opande, 2017), Igbo proverbs (Ezeifeka, 2017), Spanish proverbs (Lomotey, 2019), Dholuo proverbs (Ogutu, 2019) and Italian/French proverbs (Bletsas, 2020). In spite of these linguistic studies on metaphor, gender and proverbs in varied sociocultural contexts, conceptual metaphorisations in gendered Yoruba proverbs still remain largely under-researched. Linguists have only studied 
gender bias in Yoruba proverbs from syntactic-semantic perspectives (Asiyanbola, 2007), feminist linguistic/literary perspectives (Owoeye, 2007; Adetunji, 2010; Akinnameji, 2020), comparative perspectives (Yusuf, 2002) and critical discoursal perspectives (Ademowo \& Balogun, 2015), but not from conceptual metaphoric feminist perspectives. This study seeks to fill this gap by examining conceptual metaphorisations in gender-based Yoruba proverbs using a linguistic approach which includes insights from the conceptual metaphor theory (CMT) and feminist critical discourse analysis (FCDA).

Therefore, the primary aim of this study is to analyse critically the metaphorical concepts inherent in select gender-based Yoruba proverbs, with a view to gaining insights into the nature of gender roles and relations in traditional Yoruba culture. Inasmuch as most gender-based Yoruba proverbs are metaphorically conceptualised, an exploration of their metaphorisation would enhance adequate understanding of how women are represented and understood in the conceptual mind of the Yoruba.

\section{Conceptual Metaphor: The Theoretical Base}

In the episteme of language, metaphors are linguistic phenomenon commonly deployed for poetic fantasy. On the contrary, metaphor is not just linguistic in nature; it is intrinsically conceptual. By implication, the whole conceptual mentalese of man (thoughts, experiences and actions) is metaphorically structured (Lakoff \& Johnson, 1980a, 1980b; Kövecses, 2010). Herein lies the thrust of Lakoff and Johnson's (1980a, 1980b) cognitive linguistic postulate on metaphor known as conceptual metaphor theory (CMT), the adopted analytical tool in the present study.

CMT enables us to comprehend or construe one aspect of a concept in terms of another: it is basically used to portray, describe, represent or understand one thing in terms of another (ibid.). It thus synthesises linguistic phenomena and human conceptual system with cultural experiential variables (Kövecses, 2010). We can thus think and talk (conceptualise) about life, arguments and ideas in terms of journeys, war and food, respectively (Kövecses, 2010). For instance, the concept argument and the conceptual metaphor argument is war (Lakoff \& Johnson, 1980b), explain that we do not just talk about argument, we win or lose argument; and the action of arguing is partially structured by the concept metaphor, argument is war, which is reflected in some of the expressions hereunder:

"Your claims are indefensible.

He attacked every weak point in my argument...

I demolished his argument..." (p. 4).

In the CMT, one conceptual domain is partially construed in terms of another; hence, "conceptual domain $a$ is conceptual domain b, which is what is called a conceptual metaphor" (Kövecses, 2010, p. 4). And conceptual domains represent conceptual schemas which "constitute cognitive models of some aspects of the world, models that we use in comprehending our experience and in reasoning about it. Cognitive models are not conscious models; they are unconscious and used automatically and effortlessly" (Lakoff \& Turner, 1989, pp. 65-66 as cited in Osisanwo, 2017, p. 22). A conceptual metaphor thus has two conceptual domains - the source domain and the target 
domain, where one domain is construed in terms of the other (Kövecses, 2010, p. 4). The source domain is the domain where conceptual metaphors are drawn from while the target is the domain being construed via the source domain. Therefore, life, argument and ideas as earlier demonstrated are target domains while journeys, war and food are source domains (Kövecses, 2010). By implication, conceptual metaphors basically use more abstract concepts as target and more concrete/physical/spatial/tangible concepts as source.

In addition, conceptual metaphors can be realised in metaphorical linguistic expressions; in other words, linguistic expressions, which are "ways of talking", make manifest and explicit conceptual metaphors, which are "ways of thinking" (Kövecses, 2010, pp. 7 \& 33). Since metaphorical linguistic expressions in language are systematically tied to metaphorical concepts, metaphorical proverbial discourses can thus be used to study metaphorical concepts about women in order to understand women's representation in Yoruba culture.

However, conceptual metaphors could also manifest in non-linguistic resources such as images, signs, drawings, pictures, sounds, colours, myths, etc. This thus reveals that conceptual metaphors could be construed via linguistic and/or non-linguistic modes, thereby giving rise to monomodal and multimodal metaphorisations in the cognitivists' paradigm (Osisanwo, 2017). However, this paper focuses on linguistic metaphorisations, specifically metaphorical proverbial expressions.

To complement the CMT in this study is Feminist Critical Discourse Analysis (FCDA), a blend of critical discourse and feminist studies that seeks to achieve social emancipation. The theory explores the operations of gender ideology and power asymmetries in discourses in the institutionalisation and sustenance of hierarchically gendered social orders (Lazar, 2007, p. 141). It advances a feminist orientation in critical discourse analysis by proposing five interrelated tenets for a feminist discourse practice, as outlined below:

- Feminist Analytical Activism: FCDA is analytically resistant to all forms of discursive manifestations of institutionalised gender inequalities and power asymmetries as it critiques "discourses which sustain a patriarchal social order - relations of power that systematically privilege men as a social group, and disadvantage, exclude, and disempower women as a social group" (Lazar, 2007, p. 145).

- Gender as Ideological Structure: FCDA posits that the mainstream gender conception is "an ideological structure that divides people into two classes, men and women, based on a hierarchical relation of domination and subordination, respectively", which must therefore be resisted (Lazar, 2007, p.146).

- Complexity of Gender and Power Relations: FCDA explores the dynamics of gender and power relations in diverse cultures and within different time frames.

- Discourse in the (De)construction of Gender: In Feminist CDA, discourse is a major "element of social practices" (Lazar, 2007, p. 149). Therefore, FCDA focuses on how gender ideology is discursively (co)constructed, sustained and resisted in diverse social orders.

- Critical Reflexivity as Praxis: FCDA as theory and practice utilises knowledge about social practices to resist gendered social orders and achieve social emancipation and transformation (ibid.) 
FCDA, with its focus on the analysis of gendered discourse practices aimed at achieving gender balance, provides an enriching blend with the CMT in critiquing women's metaphorisations in gender-based Yoruba proverbial discourses.

\section{Research Methodology}

The data for this study comprise 100 Yoruba proverbs on women. These proverbs were purposively selected from collections in published and unpublished sources. The published sources were proverbs from Kolawole (1998), Olojede (2012), Owomoyela (2005), Olasupo et al. (2012) Asiyanbola (2005) and Odeyemi (2013) while the unpublished collections, gathered via semi-structured interview, consist of anonymous proverbs on women being used in the day-today interactions among the Yoruba in Oyo State, Southwest Nigeria. Yoruba proverbs are chosen in this study owing to the researcher's familiarity with the Yoruba Language and the Oyo indigenes. And the selection criterion for the proverbs is hinged on their popular usage and easy translatability to English. For easy analysis, the proverbs were each translated from Yoruba into English; and to also facilitate translation exactness, some of the literal contents of the proverbs in the study differ slightly from the ones presented in the published collections. Worthy of mention is the fact that the proverbs were translated based on their literal or semantic meaning, although according to Fakoya (2007), context basically defines proverbial usage in any culture.

Subsequent upon translation, the obtained corpus of proverbs was subjected to conceptual metaphorical analysis with a view to exploring metaphorisations in the representation of women in the proverbial expressions. The Conceptual Metaphor Theory (CMT) and some aspects of Feminist Critical Discourse Analysis (FCDA) guide the analysis. To elicit metaphorical propositions in the dataset at the linguistic level, Pragglejaz Group's (2007, p. 3 as cited in Kövecses, 2010, p. 5) Metaphor Identification Procedure (MIP) was adopted. The MIP is highlighted hereunder:

1) Read the entire text-discourse to establish a general understanding of the meaning.

2) Determine the lexical units in the text-discourse:

(a) For each lexical unit in the text, establish its meaning in context, that is, how it applies to an entity, relation, or attribute in the situation evoked by the text (contextual meaning). Take into account what comes before and after the lexical unit.

(b) For each lexical unit, determine if it has a more basic contemporary meaning in other contexts than the one in the given context. For our purposes, basic meanings tend to be:

- More concrete (what they evoke is easier to imagine, see, hear, feel, smell, and taste);

- Related to bodily action;

- More precise (as opposed to vague);

- Historically older.

Basic meanings are not necessarily the most frequent meanings of the lexical unit.

(c) If the lexical unit has a more basic current-contemporary meaning in other contexts than the given context, decide whether the contextual meaning contrasts with the basic meaning but can be understood in comparison with it.

3) If yes, mark the lexical unit as metaphorical. (Pragglejaz Group, 2007, p. 3) 
In what follows, the analysis is organised in two sections. First, the conceptual metaphors in the corpus are elicited and analysed to determine women's metaphorisations in the Yoruba culture. And then, a feminist critique of the elicited conceptual metaphors is undertaken in order to investigate how the metaphors are implicated in gender ideology.

\subsection{Analysis and Findings}

In the dataset, four (4) conceptual metaphors structure women: women are weaklings; women are evil; women are whores; and women are procreants, as represented in Figure 1 hereunder:

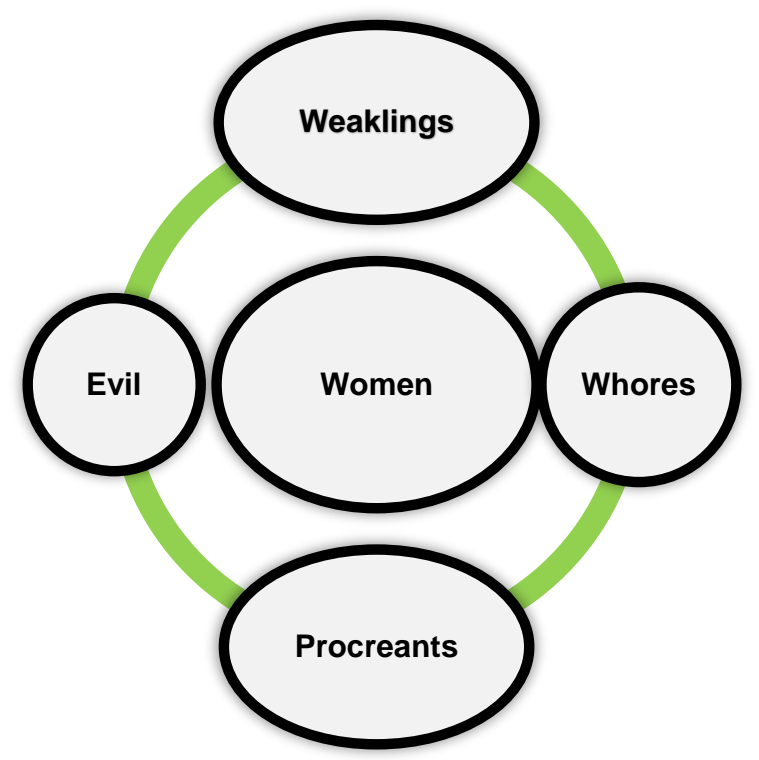

Figure 1: Conceptual Metaphors of Women in Yoruba Proverbs

In achieving the above conceptual metaphorisations in the proverbial discourse, the CMT principles of mappings, entailments, highlighting and hiding as well as the up-down orientation are amply deployed. Each principle is defined hereinafter:

- Metaphorical Mappings: refer to "a set of systematic correspondences between the source and the target in the sense that constituent conceptual elements of b correspond to constituent elements of $a^{\prime \prime}$ (Kövecses, 2010, p. 7).

- Metaphorical Entailments: In the metaphorical process, rich additional knowledge about a source, distinct from the conventional knowledge, could be mapped onto the target, such knowledge realise metaphorical entailments (p. 122). So, metaphorical entailments are additional knowledge about the constituent elements of a source implicated in the metaphorical mappings between the basic constituents.

- Metaphorical Highlighting and Hiding: conceptual metaphors highlight only some partial aspects of the concept being understood in terms of others, and consequently hide/mask other aspects of these concepts. This explains the principles of highlighting and hiding in the theory (Lakoff \& Johnson, 1980b, pp. 11-12).

- Up-Down Orientation: This refers to a type of orientational/spatial metaphors that make target concepts more coherent. Up-Down orientation is synonymous with upwarddownward orientations correspondingly. Upward orientation represents positive 
evaluation of target concepts while negative orientation depicts negative orientation; upward and downward orientations are thus spatial image schemas (ibid.)

\subsection{Women Are Weaklings}

In the corpus, women are conceptually metaphorise as weaklings, which thus gives them an essentially inferior role in the Yoruba culture. The metaphor maps the source domain (weakling) onto the target domain (women) thereby portraying the female gender as physically and/or morally weak, cowardly and of a lower status. This conceptual metaphor, women are weaklings, is reflected by a wide variety of expressions in the proverbs which all form a systematic way of representing females in the Yoruba culture. A few samples from the dataset are outlined below:

Ex. 1: "Ile t'obinrin tin se atoto arere, igi arere ni hu nibe. (Any family that allows the women to be vocal will see the abnormal growth of the wild Arere tree inside the house.)" (Kolawole, 1998, p. 19)

Ex. 2: "Obinrin o șéé finú hàn. (A woman is not suitable to expose one's secrets to.) (Interview)"

Ex. 3: "Obinrin-ín tẹ ilú, ó tú. (A woman founds a town, and it scatters.)" (Owomoyela: 2005, p. 377)

Ex. 4: "Awo egungun lobinrin le se, awo gelede lobinrin le mo, t'obinrin ba fo ju doro, oro agbee (Only the secret cults of Masquerade and Gelede could women be part of, if they dare to be part of that of Oro, Oro would consume them.)" (Olasupo et al 2012, p. 14)

Ex. 5: "Etí lobinrín fi ńgbo ohùn oro (It is only with the ears that a woman hears the voice of Orò.)" (Owomoyela, 2005, p. 64)

Ex. 6: "Obinrin tó gégi nígbó Oro, ó gé àgémọ. (A woman who cuts wood in the grove of Orò has cut her last.)" (Owomoyela, 2005, p. 182)

Structurally, Exs. 1, 3, 4 and 6 are negative double propositions consisting of two clauses - the signal clause and the completive clause - where the latter completes the former by placing in the foreground the negative orientation of each proposition while Exs. 2 and 5 are both negative single propositions. These excerpts are negative propositions in that women are negatively evaluated in each thereby giving the target concept a downward image schema; hence, women are given a downward orientation. Although the word "weakling" does not occur in any of the proverbs, women are metaphorically conceptualised as weaklings in each excerpt. Systematic correspondences (systematic similarities) between women and weakling are portrayed in the excerpts by mapping some conceptual elements of the source (weakling) to the target (women). The excerpts thus index some major constituent elements of weaklings: have no voice (Ex. 1); indiscreet/unreliable (Ex. 2); leadership deficient (Ex. 3); lacking in courage (Ex. 5); and, powerless (Ex. 1-6). These constituent elements of weakling, the source, can be mapped unto women, the target, to highlight a set of correspondences (similarities) between both. These 
metaphorical mappings suggest that certain constituent elements of weakling correspond systematically to some constituent elements of women to yield 'Target (Women) - Source (Weaklings)' conceptualisation. These mappings thus provide a generic structure for construing women among the Yoruba.

Furthermore, the source nominal, weakling, is implicitly set against its antonym, strongling, which further corresponds to the mapping that the target nominal, women, is also being set against its opposite, men. Although the nominal men does not appear at all in the proverbs, our knowledge about the biological sexes (male and female) enables us to make sense of the proverbs; and this knowledge manifests in the metaphorical entailment that women are being pitched against men in antagonistic ambience. The non-constituent element of the concept of weakling in the conceptual metaphor is the antonym strongling against which weakling is judged; and this non-constituent element of the source can be used to understand that the target women are implicitly pitched against men in a contest of superiority. The activation of this nonconstituent element of the source therefore yields the following metaphorical entailments, otherwise known as sub-metaphors: women versus men; women are inferior; and men are superior, which are all masked/hidden in the proverbial discourse, as represented in Figure 2:

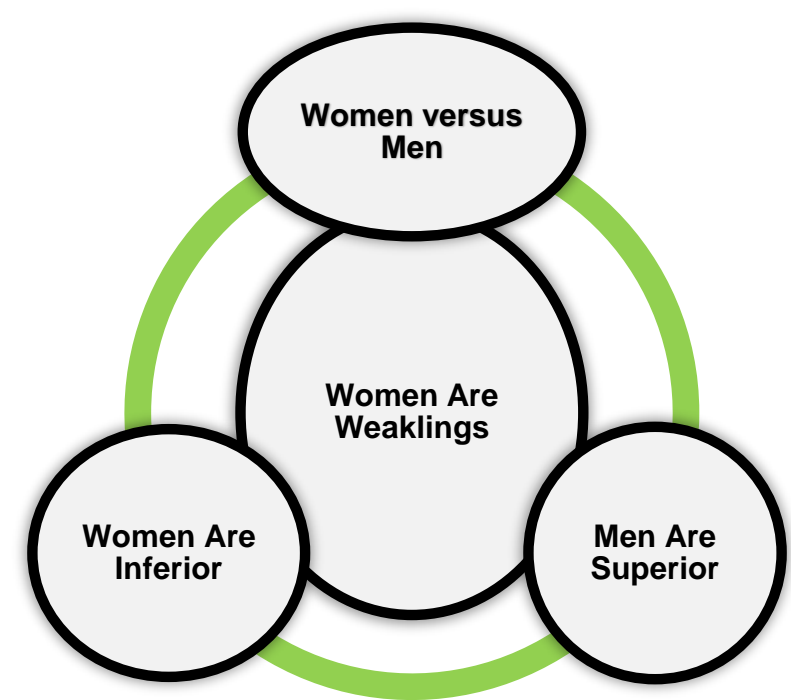

Figure 2: Sub-metaphors of the women are weaklings conceptual metaphor

\subsection{Women Are Evil}

Women Are Evil is another conceptual metaphor prominent in the corpus. Women are metaphorically conceptualised in the proverbs as evil by mapping the source domain (evil) unto the target domain (women). The concept of women and the conceptual metaphor "women are evil" structures not only how women are represented but also how they are understood. The conceptualisation overtly manifests in metaphorical expressions such as "witches", "not good" and "mischief" which construe women as malevolent and inhuman. Excerpts 7 to 13 below exemplify the conceptual metaphor:

Ex. 7: "Eni ti o da aso obinrin bora, werepe lo da bora. (Anyone who covers himself with a woman's cloth covers himself with the tormenting itching of werepe fruits)": (Interview) 
Ex. 8 "O o ni obirin n'ile, o ni o o fe aje, se o o fe iya re ni? (You don't have a wife at home, yet you say you don't want to marry a witch, would you marry your mother?)" (Interview)

Ex. 9: "Obinrin bimo fun ni o pe ko ma pani, obinrin ko bimo fun ni o pe ko ma pani. (Whether a woman has a child for her husband or not does not prevent her from killing him; whether a woman has no child for her husband does not prevent her from killing him)" (Interview)

Ex. 10: "Iyàzó mi i o sunwo; nitorí ọmo ni mo șe fe ẹ; ẹni méló la ó wi i fún tán? ("My wife is not good, but I married her for the sake of children"; to how many people will one give that explanation?)" (Owomoyela, 2005, p. 125)

Ex. 11: "Kàkà kí ó sàn lára iyá àje, ó fi gbogbo ọmọ bí obinrin; eye ńgorí ẹyẹ. (Instead of mother witch's affairs improving, all the children she bears turn out to be female; witches now multiply)." (Owomoyela, 2005, p. 175)

Ex. 12: "Bí obinrín bá máa dán èké wo, a da aṣo dúdú bora. (When a woman wishes to engage in mischief, she wears dark clothing). (Owomoyela, 2005, p. 242)

Ex. 13: "Koto ayé, koto obinrin, àti koto ikú, okan o yàto. (The pit dug by the world, the one dug by a woman, and the one dug by death: they are all the same)." (Owomoyela, 2005, p. 376)

Structurally, Exs. 7 and 12 are also negative double propositions consisting of double clauses (the signal and the completive clauses) in which the completive clause in each explains the signal clause. In Ex. 7, a woman's clothes are compared to werepe's leaves (the leaves are notable among the Yoruba people for their tormenting itching toxicity; so, people steer clear of them). The completive clause thus explains what happens to anyone who covers himself/herself with a woman's clothes. In Ex. 12, the completive clause explains what a mischief woman wears to reveal her nature. So, the completives in both excepts are revelatory image schemas of womenkind. Exs. 8 and 10 deploy metaphoric questioning to respectively foreground the inherent witchcraft and malevolent tendencies of women; and most importantly, the metaphoric questioning in the two excerpts subtly projects the indispensability of women as wives (in Ex. 8) and mothers (in Ex. 10) in spite of their viciousness. Ex. 9 is a double proposition consisting of cross parallelism (the juxtaposition of two or more syntactic constructions slightly modified to express agreement for rhetorical effect). Proposition 1 (Obinrin bimo fun ni o pe ko ma paniWhether a woman has a child for her husband or not does not prevent her from killing him.) and Proposition2 (Obinrin ko bimo funni o pe ko ma pani - Whether a woman has no child for her husband does not prevent her from killing him) are analogous as they both represent women as murderers in spite of their motherhood status. Excerpt 13 consists of reduplication (repeated words) meant to equate women with death and the world while Ex. 11 is made up of multiple propositions that foreground women's witchcraft tendency in order to denounce matrilineality and endorse patrilineality.

In each excerpt as demonstrated above, women are negatively evaluated and given a downward orientation. In the dataset, there are systematic correspondences between women and 
evil through the mapping of certain conceptual elements of the source (evil) to the target concept (women). The proverbs index the following constituent elements of evil: actively practices witchcraft (Ex. 1 and 11); has killing tendencies (Ex. 9 and 13); mischievous (Ex. 12); and bad outright (Ex. 10). These constituent elements of evil can thus be mapped unto women, the target concept, to highlight the correspondences between both.

As earlier explained, the source nominal evil is set in contrast against its opposite good, which also corresponds to the mapping that the conceptual metaphor, women are evil, is also implicitly set against its opposite, men are good. Our knowledge about male and female dichotomy enables us to make sense of the proverbs that they are gender-based verbal contest for superiority. The activation of this metaphorical entailment (otherwise known as the nonconstituent element of the mapping) yields the following sub-metaphors: women are witches (Exs. 8 and 11); women are potential (husband) killers (Ex. 9); and women are bad (Ex. 10), as represented in Figure 3:

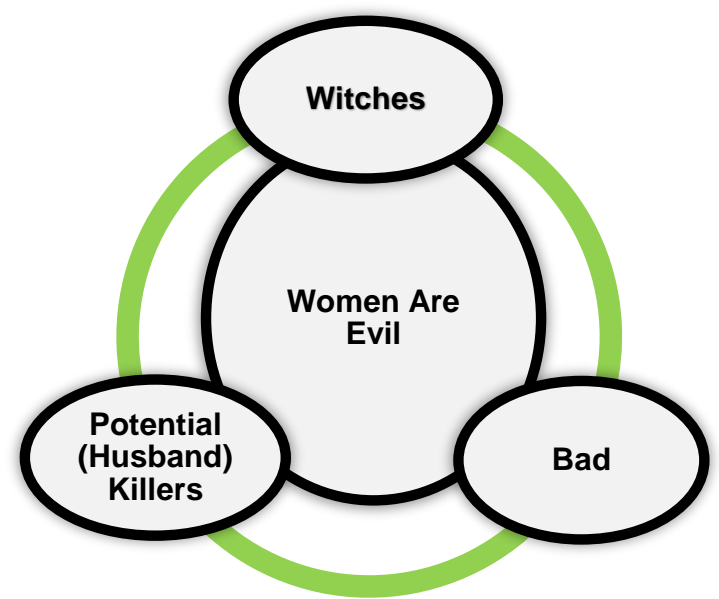

Figure 3: Sub-metaphors of the women are evil conceptual metaphor

\subsection{Women Are Whores}

Furthermore, Women Are Whores is another conceptual metaphor in the corpus. Women are metaphorised as whores to denote their sexual promiscuity. The proverbial metaphorical expressions map the source domain (whore) onto the target domain (women). This particular conceptual metaphor challenges the sexual morality of womankind, as exemplified in the following examples:

Ex.14: "Awo burúkú lobìnrin lè șe, obìnrin lálè mẹâ, mẹfẹefà ò mọra wọn. (Women are capable of only vicious secrecy: a woman has six male concubines, (and) the six do not know each other)." (Olojede, 2012, p. 8)

Ex. 15: "Bí obinrin o bá gbé ilé tó méji., ki i mọ èyí tó sàn. (If a woman has not lived in at least two homes, she never knows which is better or if a woman has not sexed two men, she never knows which is better)." (Owomoyela, 2005, p. 111)

Ex. 16: "Okó ilé ki i jọ obinrin lójú, àfi bó bá dó tita. (The penis at home never impresses the woman, unless she sexes one outside the home)." (Interview) 
Ex. 17: “Gbogbo obinrin ló ńgbéșe, èyí tó bá șe tie láṣejù laráyé ńpè láṣewó. (All women are unfaithful; only those who know no moderation are put down as harlots)." (Owomoyela, 2005, p. 170)

Ex. 18: "Bí a bá ká okó mo obinrin nídí, á ní kùkú ni. (If a woman is caught with a penis in a woman's vagina, she will argue that it is only a corncob)." (Interview)

Ex. 19: "Bí o rí i, wà pé o o rí; ọko fún ọ lówó, àlé gbà á ná. (If you saw it, you would say you did not; your husband gave you money and your male concubine spends it)." (Owomoyela, 2005, p. 242)

Ex. 20: "Obinrin abàlèmefà: àlè mefà o mọ ara wọn. (A woman has six male concubines: the six never know about one another)." (Owomoyela, 2005, p. 250)

Ex. 21: "Obinrín re ilé àlè, ó fi ilé iyá e tan ọkọ jẹ. (A woman goes to her lover's house and uses her mother's home to deceive her husband)." (Owomoyela, 2005, p. 250)

Double propositions in which the completive clauses are explanatory and revealing are deployed in Exs. 16, 17, 20 and 21; conditional propositions in Exs. 15 and 18; multiple propositions are used in Exs. 14; and a complex proposition in Ex. 19; all with the intent of placing in the foreground women's promiscuity. In the proverbial propositions, there are expressions such as "male concubines", "sexes", "sexed", "harlots", "unfaithful" and "deceive" that metaphorise women as whores. Certain constituent elements of whores are mapped unto women, namely: unfaithful, deceitful, secretive, promiscuous, unsatiable, and untrustworthy. These metaphorical mappings thus give women a generic negative evaluation and a downward image schema in the Yoruba culture.

The non-constituent elements of the source (whore) map out the following metaphoric entailments: the wilfulness of women's promiscuity and its consequent result of paternity dubiety among the Yoruba. The presumed promiscuity of women in the Yoruba culture foregrounds the fact that women wilfully make themselves men's sexual objects and women's sexual indulgence makes possible paternity fraud, most especially among married women. The activation of these metaphorical entailments therefore yields the following sub-metaphors: women are men's wilful sexual objects; and women's immorality heightens paternity dubiety, as diagrammatised in Figure 4: 


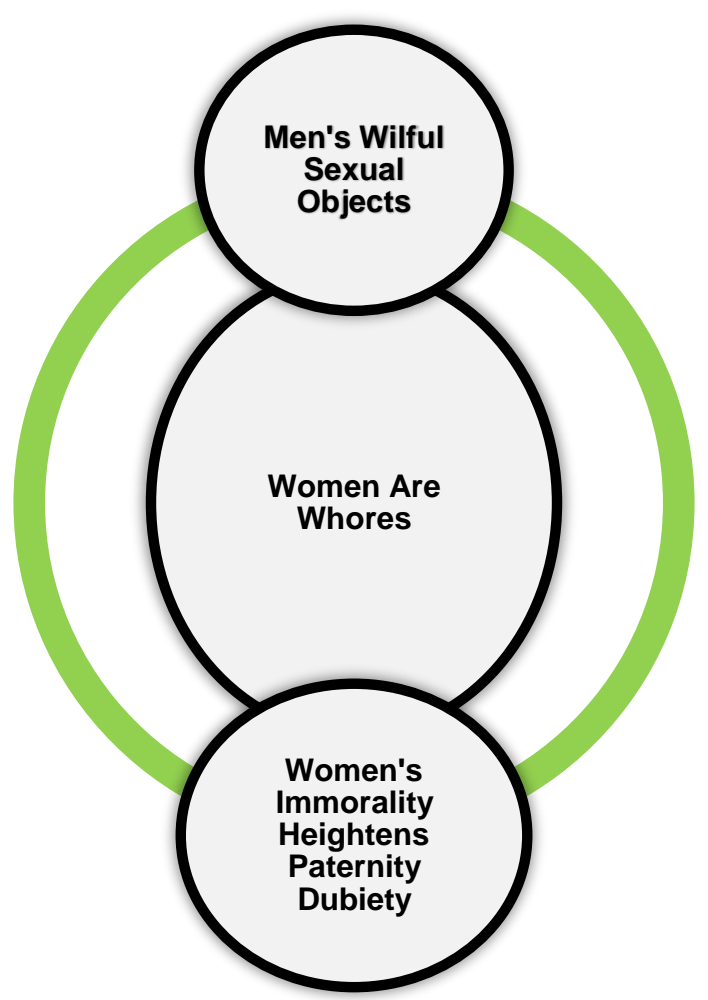

Figure 4: Sub-metaphors of the women are whores conceptual metaphor

\subsection{Women are Procreants}

Women are procreants is another conceptual metaphor in the corpus, although proverb samples that exemplify this metaphorisation are fewer in number compared to other conceptual metaphors. Its non-prominence notwithstanding, its orientational image schema for women need not be jettisoned as metaphorical expressions such as "mother", "gold", "... no deity as great as mother", and "the glory of a woman" come to the fore. The conceptual metaphor thus maps the source domain (procreant [capable of producing offspring]) unto the target domain (women) to foreground motherhood. Women are positively evaluated in this conceptual metaphor thus giving the target concept an upward image schema. The conceptualisation overtly manifests in the metaphorical reduplication of the wording "mother" which construes women as mothers thereby celebrating the reproductive and nurturing prowess of womenfolk, as exemplified in the following examples:

Ex. 22: "Iya ni Wura. (Mother is gold)." (Interview)

Ex. 23: "Orisa bi iya ko si! (There is no deity as great as mother)." (Odeyemi, 2013, p. 8)

Ex. 24: "Obinrin to bimo fun ni ti kuro lale eni. (A woman who has got a child for one is no more one's concubine)." (Asiyanbola, 2009, p. 252)

In terms of structure, Exs. 22, 23 and 24 consist of simple propositions which celebrate motherhood. The excerpts index some constituent elements of procreant: can produce offspring (Exs. 22 and 24); and nurture her young (Ex. 23 and 25). These constituent elements of procreant, 
the source, can be mapped unto women, the target, to underline the systematic correspondences between both. These mappings provide a generic structure for understanding women in the Yoruba culture.

However, the mappings above presuppose that a woman who does not or cannot conceive nor nurture her young has no glory and should not be celebrated. The mappings have streamlined the women to be celebrated in the conceptual metaphor - "women-mothers", those with the potential to reproduce offspring; hence, the mappings are exclusionary in function inasmuch as barren/infertile women do not or cannot meet the procreation and nurturing criteria. These are therefore the hidden elements of the mappings which thus entail the following submetaphors: women are mandated procreants; infertile women are non-mothers; and nonmothers are unvaluable, as depicted hereunder in Figure 5:

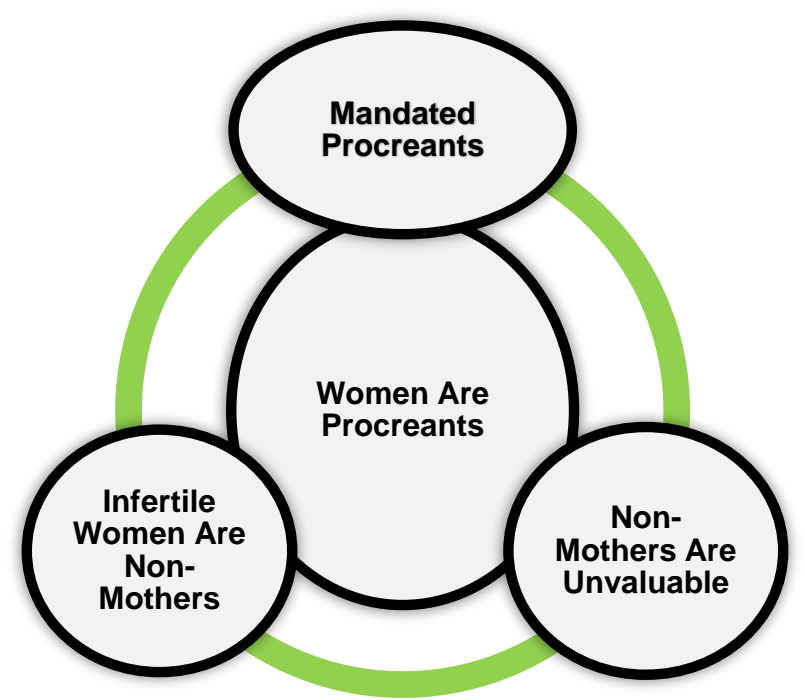

Figure 5: Sub-metaphors of the women are procreants conceptual metaphor

\subsection{A Feminist Appraisal of the Conceptual Metaphors}

The first three conceptual metaphors above women are weaklings; women are evil; and women are whores represent women negatively and generically gives them a "downward orientation"; hence, they are all down metaphors. Women are weaklings presupposes that, women are weaker to men; women are evil depicts that, women are not good (vicious and not virtuous) compared to men; and women are whores indicates that women are morally and sexually corrupt. These metaphorisations presuppose that, women are of lower quality to men; hence, they are biologically and morally inferior to men.

The fourth conceptual metaphor women are procreants assumedly underlines a positive image schema. By celebrating motherhood, the metaphor gives women a positive evaluation and an upward orientation. However, the metaphor conceptualises women as baby-machine; and not just that! The metaphor also strictly hinges women's invaluableness to her reproductive power without which she is considered worthless. By implication, infertile women are valueless. Just like the first three metaphors, this last conceptual metaphor also entails a down orientation as it depicts women's procreative ability as their only element of value; a notion that further perpetuates women's subordination. 
The downward image schematic basis of these four metaphors indicates that, among the Yoruba, women are highly construed negatively. From a feminist perspective therefore, this construal suggests that the ideological gender structure in the Yoruba culture advances a dual and hierarchical gender order in which women are subordinated to men. The gender construct is thus skewed in favor of men. According to Balogun (2010) and Anthonia (2019), it could be argued that most of these derogatory proverbs about women are authored by men to establish, reinforce and perpetuate their hegemonic masculinity which structures gender relations and constrains women's emancipation. As observed in the corpus, the hegemony is routinely enacted in the proverbial discourse to project the ingrain gender norms in the Yoruba culture. This explains the seemingly innocuous and legitimate schemas of the proverbs. The analyses have brought to the limelight the expected ways of being and doing a woman in the Yoruba culture. However, the construction does not portray womanhood in isolation, it also implicitly places women vis-à-vis men within a hierarchical gender structure in order to produce women's subordinated identity. Thematically, the metaphorisation underlines "being and doing womanhood" in an androcentric culture. It can be posited therefore that the examined womenfocused proverbs are blatantly misogynistic as they reveal the discursive systemic workings of hegemonic power relations operative in Yoruba traditions; hence, the Yoruba traditional gender ideology is innocuously and systemically oppressive in nature and must therefore be resisted and transformed.

Furthermore, women are not just represented as sexual objects for men's gratification in the proverbs, but the representation overtly depicts that, women themselves have advertently objectified their bodies for men's sexual pleasure. Objectification of women is thus the handiwork of women themselves, which thus shifts the blame from men to women themselves. With this, the victim-offender mapping is subverted as the metaphorisations purportedly reconceptualize women from victims to offenders, from sexual objects to sexual subjects and from being sexually passive to being sexually (hyper)active, but not as a sign of women's empowerment but their debasement, lack of morality and self-control. In sum, the metaphors construct subordinated and powerless femininity vis-à-vis hegemonic masculinity.

African proverbs generally are often seen as sacred original artifacts of culture often insulated from bowdlerization (Yitah, 2006; Balogun, 2010); a view that has circumvented the (gradual) review of oppressive proverbs against women in most African culture. Inasmuch as the FCDA's goals are social emancipation and transformation via resistance and change agenda, a critique of the conceptual metaphors in the proverbs is not geared towards mere deconstruction of the conceptual metaphors in the proverbs but towards the acknowledgement that the downward metaphorisation of women in the proverbs should be a rationale for the move to reconceptualise womanhood in the Yoruba culture using upward image schema. It is high time Yoruba women resisted these derogatory proverbs through advertent and aggressive reconstruction. In support of Balogun's (2010) views on re-construction of oppressive proverbs, advertent efforts should be geared towards making such proverbs gender-neutral with a view to restoring the esteem of Yoruba women. Although the emergence of "post-proverbials" (RajiOyelade, 1999), which are "alternate variations of conventional proverbs, mostly used humorously by the younger generation" (Aragbuwa, 2020, p. 1), promises some conscious efforts at reconstructing Yoruba proverbs, such post-proverbials still share some sexist semblances with mainstream 
proverbs. Post-proverbials only lace traditional proverbs with some modern touch, as depicted in Ex. 25 (P and PP represent tradition proverb and post-proverbial, correspondingly):

Ex. 25 (P): “Ope l'obinrin, gbogbo eni ba ni igba lowo ni i gun. (Women are promiscuous; any man with a good penis can sleep with them)." (Aragbuwa, 2020, p. 9 as cited in Ademowo \& Balogun 2015, p. 16).

PP: “Ope l'obinrin gbogbo enito ba ni condom lo $n$ ba won sun. (Women are promiscuous; anybody with a condom sleeps with them)." (Aragbuwa, 2020, p. 9 as cited in Ademowo \& Balogun 2015, p. 16).

As observed in P and PP above, post-proverbials still retain a downward orientation for women; hence, no reconceptualisation is achieved. This thus necessitates the exigencies of remetaphorising mainstream gender-based oppressive proverbs to obliterate their sexist elements, from which post-proverbials could take semblances from.

\section{Concluding Remarks}

This study has attempted a critical examination of the metaphorisation of women in a corpus of women-inclined Yoruba proverbs using the linguistic frameworks of CMT and FCDA. The examination has mirrored how women are represented in the Yoruba cultural milieu thereby expanding the literature on gender-related proverbial discourses. This study confirms that the weakling, evil, whore and procreant metaphors jointly characterise women and subconsciously shape how women are perceived in the conceptual mind of the Yoruba. These are thus the culture-bound way of conceptualising women among the Yoruba.

However, the entailment relations that subsist among these four distinct conceptual aspects of women can permit their merging into one single comprehensive conceptual metaphor - women are (in all wise) inferior (to men), which makes the conceptual metaphors to systematically cohere and share a common entailment. The systemic use of denigrating language to represent women among the Yoruba reveals the (mis)conception of the people about the female gender. In this sense, the Yoruba live by these conceptual metaphors and hinge gender relations on them. Positive traits of women that are inconsistent with these conceptual metaphors are therefore masked. There may however be cultures where women are conceptualised differently, which calls for further studies on metaphorisations of women in gender-based proverbs in other cultures.

In conclusion, the examined proverbs in this study are conceptually furnished to accomplish hegemonic masculinity. This therefore calls for the urgent need to re-conceptualise the proverbs using upward image schemas that project women positively among the Yoruba.

\section{Conflict of Interest Statement}

The authors declare no conflicts of interests. 


\section{About the Authors}

Adetutu Aragbuwa is Lecturer I in the Department of English and Literary Studies, Ekiti State University, Ado Ekiti. She holds a PhD in English Language from Obafemi Awolowo University, Ile-Ife. Her areas of specialisation are discourse analysis, feminist critical discourse analysis and computer-mediated discourse analysis.

Samuel A. Omotunde is Senior Lecturer in the Department of English and Literary Studies, Ekiti State University, Ado Ekiti. He holds a PhD in English Language from Ekiti State University, Ado Ekiti. His areas of interests include pragmatics, stylistics and discourse analysis.

\section{References}

Ademowo, A. J., \& Balogun, N. O. (2015). Postproverbial Constructions and Selected SexRelated Yoruba Proverbs and Proverbial Expressions. Antropologija 15 (2), 9-22.

Adetunji, A. (2010). Aspects of Linguistic Violence to Nigerian Women. Language Society and Culture, 31, 10-17.

Akinmameji, O. O. (2020). Proverbs and Figurative Expressions as Markers of Feminist Ideology in Selected Femi Osofisan Plays. Linguistik Online 101, 99-113.

Anthonia, M. Y. (2019). The Image of Yoruba Women in Myths and Proverbs. Nigerian Journal of Literacy and English Education 1(2), 130-138.

Aragbuwa, A. (2020). A Feminist Critical Discourse Analysis of Selected Sex-Related Yoruba Proverbs and their Post-Proverbials. Nordic Journal of African Studies 29 (1), 1-17.

Asiyanbola, A. A. (2009). English-Translated Yoruba Proverbs Associated with Women: Need for Gender Equality. África: Revista Do Centro De Estudos Africanos. USP, S. Paulo, 24-25$26,247-264$.

Asiyanbola, A. A. (2007). A Syntactic and Semiotic Analysis of some Yoruba Sexist Proverbs in English Translation: Need for Gender Balance. Nebula 4 (3), 63- 78.

Balogun, O. A. (2010). Proverbial Oppression of Women in Yoruba African Culture. Thought And Practice: A Journal of The Philosophical Association of Kenya (PAK) 2(1), 21-36.

Barasa, M. N., \& Opande, I. N. (2017). The Use of Animal Metaphors in the Representation of Women in Bukusu and Gusii Proverbs in Kenya. Africology: The Journal of Pan African Studies 10 (2), 82-108.

Bletsas, M. (2020). Gendered Metaphors in Proverbs. A Study on Italian and French. metaphorik.de 30/2020, 11-37.

Daramola, Y. (2004): Yoruba Proverbs in the Perspectives of Music. Proverbium 21, 27-34.

Daramola, A. (2007). Sokoro Sakara: A Contextual and Gender Analysis of some Offensive Yoruba Proverbial Songs. Nebula 4 (4), 121-130.

Daramola, A. (2013). A Semiotics of Aspects of English and Yoruba Proverbs. The Journal of International Social Research 6 (24), 99-108.

Doyle, C. (2007). Observations in the Diachronic Study of Proverbs. Proverbium 18, 57-76.

Estaji, A., \& Nakhavali, F. (2011). Semantic Derogation in Persian Animal Proverbs. Theory and Practice in Language Studies 1 (9), 1213-1217. 
Ezeifeka, C. R. (2017). Gender Stereotypes in Selected Igbo Proverbs. Contemporary Journal of African Studies 4 (2), 93-126.

Fakoya, A. A. (2007). Sexually-Grounded Proverbs and Discourse Relevance: Insights from Yorùbá. California Linguistic Notes XXXII (2), 1-30.

Finnegan, R. (2012). Oral Literature in Africa. New Edition [Online]. Cambridge, UK: Open Book Publishers.

Hussein, J. W. (2004). A Cultural Representation of Women in the Oromo Society. African Study Monographs 25 (3), 103-147.

Hussein, J. W. (2005). The Social and Ethno-Cultural Construction of Masculinity and Femininity in African Proverbs. African Study Monographs 26 (2), 59-87.

Kolawole, M. E. M. (Ed.) (1998). Gender Perceptions and Development in Africa: A Socio-Cultural Approach. Lagos: Arrabon Academic Publishers.

Kövecses, Z. (2010). Metaphor: A Practical Introduction (2 ${ }^{\text {nd }}$ Ed.). New York: Oxford University Press.

Lakoff, G., \& Johnson, M. (1980a). Conceptual Metaphor in Everyday Language. The Journal of Philosophy 77 (8), 453-486.

Lakoff, G., \& Johnson, M. (1980b). Metaphors We Live By. Chicago: University of Chicago Press.

Lakoff, G., \& Turner, M. (1989). More Than Cool Reason: A Field Guide to Poetic Metaphor. Chicago: University of Chicago Press. Merwin, W. S. 1973. Asian Figures. New York: Atheneum.

Lazar, M. M. (2007). Feminist Critical Discourse Analysis: Articulating A Feminist Discourse Praxis. Critical Discourse Studies 4 (2), 141-164

Lomotey, B. A. (2019). Women, Metaphors and the Legitimisation of Gender Bias in Spanish Proverbs. Journal Of International Women's Studies 20 (2), 324-339.

Mieder. W. (1993). Proverbs are never out of season: Popular wisdom in the modern age. New York, Oxford: Oxford University Press.

Mieder, W. (2004). Proverbs: A Handbook. London: Greenwood Press.

Mwihia, C. N. (2005). A Theological Analysis of African Proverbs About Women: With Reference to Proverbs from Gikuyu People of Central Kenya. A Thesis Submitted in Partial Fulfilment of the Requirements for the Degree of Master of Theology in the School of Religion and Theology at the University of Kwazulu-Natal, Pietermaritzburg-South Africa

Odeyemi, J. S. (2013). Gender Issues Among the Yorubas. The International Journal of African Catholicism 4 (1), 1-22.

Ogutu, W. A. (2019). A Pragmatic Analysis of Patriarchy and Dholuo Proverbs: The Use of Conceptual Metaphor Theory and Dominance Theory. M. A. Thesis in Linguistics. University of Nairobi, Kenya.

Oha, O. (1998). The Semantics of Female Devaluation in Igbo Proverbs. African Study Monographs $19(2), 87-102$.

Olojede, F. (2012). (Un)Popular images of women in Yoruba popular culture: A quest for human dignity. In J. Claassens \& S. Viljoen (eds.). Sacred Selves: Essays on Gender, Religion and Popular Culture (pp. 187-205). Griffel, Cape Town. 
Olasupo, F. A., Kikelomo, O. V., \& Adeniran, J. A. (2012). Proverbs and Gender Equalities and Equities in African Cultueres: Yoruba Culture as a Case Study. Global Journal of Human Social Science Arts \& Humanities 12 (13), 10-26.

Osisanwo, A. (2017). Conceptual Metaphors in Newspaper Reportage of the War on Boko Haram Terrorism in Nigeria. Ibadan Journal of Humanistic Studies 27, 19-36.

Owomoyela, O. (2005). Yoruba Proverbs. Lincoln and London: University of Nebraska Press.

Owoeye, O. (2007). Feminism in Osofisan's Plays: New Thinking. UNAD Studies in Language and Literature (USILL), 2/2, 79-93.

Pragglejaz Group (2007). MIP: A Method for Identifying Metaphorically Used Words in Discourse. Metaphor and Symbol, 22 (1), 1-39. http://dx.doi.org/10.1080/10926480709336752 Raji-Oyelade, A. (1999). Postproverbials in Yoruba Culture: A Playful Blasphemy. Research in African Literatures 30 (1), 74-82.

Sibanda, N. (2015). An Analysis of the Significance of Myths and Proverbs as African Philosophies of Peace and Justice: A Case of the Ndebele, Shona and Tonga Tribes from Zimbabwe and the Igbo from Nigeria. IOSR Journal of Humanities and Social Science (IOSRJHSS) 20 (4), 01-06.

Salami, Y. K. (2004). Yoruba Proverbs and Democratic Ethos. Proverbium 21, 315-328.

Saleh, Y. S. (2014). A Contrastive Analysis of English and Hausa Proverbs in Selected Texts. M.Ed., Department of Arts and Social Science Education, Faculty of Education, Ahmadu Bello University, Zaria

Yitah, H. (2006). Throwing Stones in Jest: Kasena Women's "Proverbial" Revolt. Oral Tradition, 21(2), 233-249.

Yusuf, Y. K. (2002). Sexism, English and Yoruba. Linguistik Online 11(2), 7-23. 
Creative Commons licensing terms

Author(s) will retain the copyright of their published articles agreeing that a Creative Commons Attribution 4.0 International License (CC BY 4.0) terms will be applied to their work. Under the terms of this license, no permission is required from the author(s) or publisher for members of the community to copy, distribute, transmit or adapt the article content, providing a proper, prominent and unambiguous attribution to the authors in a manner that makes clear that the materials are being reused under permission of a Creative Commons License. Views, opinions and conclusions expressed in this research article are views, opinions and conclusions of the author(s). and European Journal of Literature, Language and Linguistics Studies shall not be responsible or answerable for any loss, damage or liability caused in relation to/arising out of conflicts of interest, copyright violations and inappropriate or inaccurate use of any kind content related or integrated into the research work. All the published works are meeting the Open Access Publishing requirements and can be freely accessed, shared, modified, distributed and used in educational, commercial and non-commercial purposes under a Creative Commons Attribution 4.0 International License (CC BY 4.0). 